\title{
Applying Soybean Oil to Dormant Peach Trees Alters Internal Atmosphere, Reduces Respiration, Delays Bloom, and Thins Flower Buds
}

\author{
R.E. Myers ${ }^{1}$, D.E. Deyton ${ }^{2}$, and C.E Sams ${ }^{3}$ \\ Department of Plant and Soil Science, University of Tennessee, Knoxville, TN 37901-1071
}

Additional index words. Prunus persica, respiration, phenology, fruit thinning, ethylene, oxygen

\begin{abstract}
Dormant 'Georgia Belle' peach [Prunus persica (L.) Batsch.] trees were sprayed in early February 1992 with single applications of $0 \%, 2.5 \%, 5.0 \%, 10.0 \%$, or $20.0 \%(\mathrm{v} / \mathrm{v})$ crude soybean oil. 'Redhaven' trees were sprayed in February 1993 with single applications of $0 \%, 2.5 \%, 5.0 \%, 10.0 \%$, or $15 \%$ degummed soybean oil. Additional treatments of two applications of $2.5 \%$ or $5.0 \%$ oil were included each year. Both crude and degummed soybean oil treatments interfered with escape of respiratory $\mathrm{CO}_{2}$ from shoots and increased internal $\mathrm{CO}_{2}$ concentrations in shoots for up to 8 days compared to untreated trees. Respiration rates, relative to controls, were decreased for 8 days following treatment, indicating a feedback inhibition of respiration by the elevated $\mathrm{CO}_{2}$. Thus, an internal controlled atmosphere condition was created. Ethylene evolution was elevated for 28 days after treatment. Flower bud development was delayed by treating trees with $5 \%$ crude or degummed soybean oil. Trees treated with $10 \%$ crude or degummed soybean oil bloomed 6 days later than untreated trees. Repeated sprays of one half concentration delayed bloom an additional four days in 1992, but $<1$ day in 1993 compared to a single spray of the same total concentration. Application of soybean oil caused bud damage and reduced flower bud density (number of flower buds/cm branch length) at anthesis. In a trial comparing petroleum oil and degummed soybean oil, yields of trees treated with $6 \%$ or $9 \%$ soybean oil were $17 \%$ greater than the untreated trees and $29 \%$ more than petroleum treated trees. These results suggest that applying soybean oil delays date of peach bloom and may be used as a bloom thinner.
\end{abstract}

A limiting factor for peach production is cold damage to fruit buds caused by late spring freezes. The use of dormant sprays of $2 \%-3 \%$ petroleum oil for insect control on fruit trees has been commonplace since the 1920s. Farrar and Kelley (1935) reported that applications of $8 \%$ petroleum oil resulted in a striking retardation of early season apple bloom and foliage development. Call and Seeley (1989) reported that petroleum oil applied at the end of endodormancy delayed flower bud development, increased cold hardiness, and delayed peach bloom by 5 days. Deyton et al. ( 1992) reported that application of $6 \%$ to $12 \%$ petroleum oil delayed peach bloom but caused bud death at higher oil concentrations. Burroughs (1923) suggested that dormant oil sprays might retard bud development due to an accumulation of $\mathrm{CO}_{2}$ or a deficiency of $\mathrm{O}_{2}$ resulting from the envelopment of the bud with oil. More recently, Saltveit (1982) suggested that analyses of internal concentrations of gases in plant material provides a measure of physiological activity. Deyton et al. (1992) found that application of petroleum oil at dormant stages elevated internal $\mathrm{CO}_{2}$ concentrations in shoots for 6 days and delayed bloom. Storage of fruit in an atmosphere high in $\mathrm{CO}_{2}$ and low in $\mathrm{O}_{2}$ (controlled atmosphere (CA) storage) has been shown to reduce fruit respiration (Smock, 1978). A similar atmosphere in the shoots could result from oil envelopment.

Current research (Pless et al., 1995) shows that dormant application of emulsified soybean oil controls scale insects on fruit trees and thus may substitute for petroleum oil. Soybean oil may also be

Received for publication 17 Mar, 1995. Accepted for publication 17 July 1995, We thank the Tennessee Soybean Board and United Soybean Board for providing financial support for this study. The technical assistance of John Cummins is gratefully acknowledged. The cost of publishing this paper was defrayed in part by the payment of page charges. Under postal regulations, this paper therefore must be hereby marked advertisement solely to indicate this fact.

'Graduate student.

${ }^{2}$ Associate professor.

${ }^{3}$ Professor. equal or superior to petroleum oil in restricting gas exchange in peach shoots and delaying bloom.

The objectives of this study were to determine if applying soybean oil to dormant peach trees affects 1) shoot respiration and internal concentrations of $\mathrm{CO}_{2}$ and $\mathrm{O}_{2}, 2$ ) peach flower bud development and time of anthesis, 3) flower bud death, and 4) crop yield.

\section{Materials and Methods}

Experiment 1. 'Georgia Belle' peach trees in a commercial orchard at Lenoir City, Term. were treated with $\mathrm{O}$ (untreated), $2.5 \%, 5 \%, 10 \%$, or $20 \%(\mathrm{v} / \mathrm{v})$ crude soybean oil (CSO) (Archer Daniels Midland, Chattanooga, Term.) plus 0.6\% Triton AG 44 emulsifier (Rohm and Haas, Philadelphia) on 11 Feb. 1992 [49 days before bloom (DBB) of controls]. A treatment of repeated applications of 5\% CSO [11 Feb. (49 DBB) and 24 Feb. (36 DBB)] was included in the experiment. Treatments were applied by handgun until runoff. Treatments were arranged in an incomplete block design with nine blocks containing four single tree plots (a total of six replicates).

Eight 38 to $50 \mathrm{~cm}$ long shoots were randomly sampled from each tree at $1,3,7,9,13,15$, and 19 days after initial treatment for determination of internal atmosphere and respiration. Trees receiving repeated applications were not sampled until after the second application. Shoots were collected from 1300- 1400 HR and stored overnight in a cooler at 3 to $4 \mathrm{C}$. The shoots were removed from the cooler the following morning and incubated at $21 \pm 1 \mathrm{C}$ for $2 \mathrm{~h}$. The $8-\mathrm{cm}$ medial portion of the shoots was retained for analysis. The internal atmosphere of $8-\mathrm{cm}$ sections of shoots (with attached buds) was extracted by placing shoots in an inverted glass funnel in water enclosed in a vacuum chamber, as described by Saltveit ( 1982). A partial vacuum $(-90 \pm 5 \mathrm{kPa})$ was applied with a vacuum pump (model DD20; Precision Scientific, Chicago) until no more bubbles were evident from the stems ( 2 rein). After return to atmospheric pressure, a 5-ml sample of gas was removed with a syringe through a serum stopper in the gas funnel. The $\mathrm{CO}_{2}$ and 
$\mathrm{O}_{2}$ content of the internal atmosphere samples was measured with a gas chromatography (CC) (model 8A, with a molecular sieve column; Shimadzu, Columbia, Md.). Before submerging shoots in the water, gases in the water were removed by applying partial vacuum to the water until no more bubbles were evident.

Phonological development of fruit buds was rated periodically (scale: $1=$ dormant, 2 = first swell, $3=$ green calyx, $4=$ red calyx, 5 $=$ first pink, and $6=$ first bloom) from the time of treatment until first bloom. The trees were then rated for percent open bloom. Flower bud death was determined by tagging 10 shoots per tree, measuring the shoot length, and counting the number of flower buds at treatment and number of live (enlarged) buds on 24 Mar. Flower bud density (no. flower buds/cm shoot length) (Westwood, 1993) was determined. Three buds from each of the basal, medial, and apical thirds of shoots were randomly sampled per tree. The buds were dissected and rated as healthy or damaged. A freeze (-6C) on 3 Apr. 1992 killed all fruit, so yield data were not collected. Data were analyzed using the General Linear Mixed Models (GLMM) statistical program (Blouin and Saxton, 1990).

Experiment 2. In 1993, degummed (slightly refined) soybean oil (DSO) was used because it was a more uniform product than crude oil. Our preliminary experiment indicated that crude and degummed oil had the same effect on bloom delay (data not shown). Three year old 'Redhaven' peach trees at the Knoxville Experiment Station were sprayed to runoff on 3 Feb. 1993 (62 DBB) with a single application of $0 \%$ (untreated), $2.5 \%, 5 \%, 10 \%$, or $15 \%(\mathrm{v} / \mathrm{v})$ degummed soybean oil with $0.6 \%$ Latron $\mathrm{AG} 44 \mathrm{M}$ emulsifier. Repeated applications of 2.570 or $5 \%$ DSO were also applied to trees on 3 Feb. (62 DBB) and 17 Feb. (48 DBB). Treatments were arranged in a randomized complete block design with 6 replications. Eight shoots were collected 1, 5, 8, 15, 18, and 21 days after initial treatment. Trees receiving repeated applications were not sampled until after the second treatment. Internal atmosphere of shoots was measured as described in Experiment 1.

Five additional shoots per tree were randomly collected on each sampling date, cut into $12-\mathrm{cm}$ sections, fresh weights determined, and then placed into a septum-capped 55-ml test tube containing 5-ml of deionized distilled $\mathrm{H}_{2} \mathrm{O}$. After $1 \mathrm{~h}$ at $21 \pm 1 \mathrm{C}$, a 5-ml sample of atmosphere within the tube was collected by syringe and respiration ( $\mathrm{CO}_{2}$ production and $\mathrm{O}_{2}$ use) and ethylene production rates were determined by gas chromatography. The $\mathrm{CO}$, and $\mathrm{O}_{2}$ were analyzed on the gas chromatography described in Experiment 1 and ethylene was analyzed on a gas chromatography, (model 8A; Shimadzu, Japan), with an activated alumina column.

Fruit bud development and percent open bloom were determined as described above. The peach crop was not thinned to determine the effect of the oil concentration on crop density. Total number and weight of the fruit was recorded at harvest. Data were analyzed using the Statistical Analysis System (SAS Institute, Cary, N.C.)

Experiment. 'Redhaven' peach trees at the Middle Tennessee Experiment Station (Spring Hill) were treated on 9 Feb. 1993 with 0 (untreated), $6 \%, 9 \%$, or $12 \%$ degummed soybean oil (with $0.6 \%$ Latron AG44M emulsifier) or petroleum oil (Drexel Chemical Co., Memphis, Term.). Treatments were arranged in an incomplete block design with 8 blocks and four replications. Fruit bud phenology was determined as described above. Ten shoots per tree were tagged and flower bud density (no. flower buds/cm of shoot) determined on 22 Feb. (43 DBB). Bloom density (blossoms $/ \mathrm{cm}$ of shoot length) was determined on 1 Apr. Yield was determined as described above. Data were analyzed utilizing the General Linear Mixed Models (GLMM) statistical program (Blouin and Saxton, 1990).

\section{Results and Discussion}

Experiment 1. The internal $\mathrm{CO}_{2}$ levels of untreated shoots (with attached buds) averaged $1.12 \%$ of the internal atmosphere during the period from the day before treatment (10 Feb. 1992) until 30 days after treatment (10 Mar.), with daily means ranging from $0.58 \%$ to $2.21 \%$. (Fig. 1). The internal $\mathrm{CO}_{2}$ concentration of shoots from trees treated with $2.5 \% \mathrm{CSO}$ was at least $33 \%$ higher than that of untreated shoots on the first and third day after treatment. The $\mathrm{CO}_{2}$ concentrations of shoots treated with $5 \%$ to $20 \% \mathrm{CSO}$ were more than double the untreated shoots on the third day after treatment (Fig. 1). Internal $\mathrm{CO}_{2}$ concentration of shoots treated with $20 \%$ CSO remained higher $(P \leq 0.01)$ than the control through the ninth day after treatment. Shoots that received a second application of 5\% CSO 12 days after initial treatment had $\mathrm{CO}_{2}$ concentrations more than double those of the untreated shoots or shoots treated with the single application of $10 \% \mathrm{CSO}$ and remained higher on the third day after treatment $(P \leq 0.01)$.

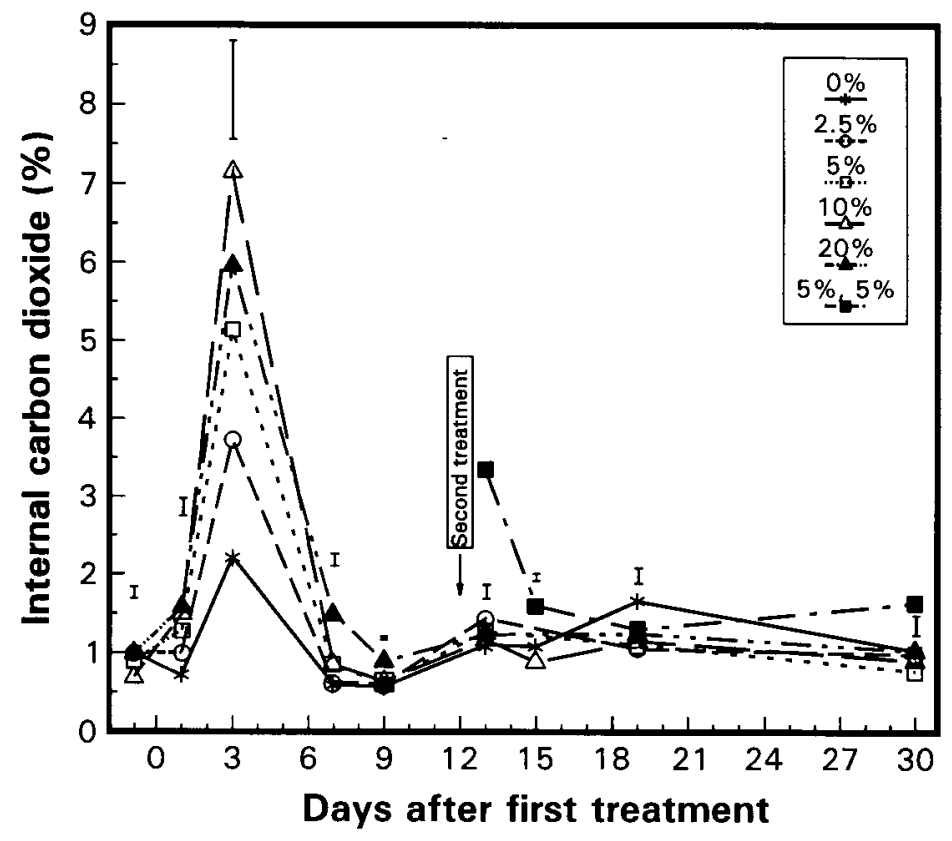

Fig. 1. Internal carbon dioxide content of stems from 'Georgia Belle' peach trees treated with $0 \%, 2.5 \%, 5.0 \%, 10 \%$, or $20 \%$ crude soybean oil on 11 Feb. or with $5 \%$ crude soybean oil on 11 and 24 Feb. 1992. Vertical bars $=$ SE,

The $\mathrm{O}_{2}$ levels within untreated shoots averaged $3.5 \%$ from the day before treatment to 30 days after treatment and varied from a low of $1.3 \%$ on $20 \mathrm{Feb}$. to a high of $9.5 \%$ on $18 \mathrm{Feb}$. (data not shown). Young and Blankenship (1991) found that storage of apple trees in low-oxygen atmosphere (3\%) delayed bud break. We detected no consistent effect of $\mathrm{CSO}$ on $\mathrm{O}_{2}$ concentration within shoots. Thus, the enclosure of shoots with soybean oil appears to affect $\mathrm{CO}_{2}$ levels more than $\mathrm{O}_{2}$ levels, implying that the oil may act as a film to restrict diffusion of $\mathrm{CO}_{2}$ but with micropores that allow more diffusion of $\mathrm{O}_{2}$ than $\mathrm{CO}_{2}$ (Robertson, 1993). The interference with diffusion of $\mathrm{CO}_{2}$ out of shoots probably results in the elevated internal concentrations. The principal effects of increased $\mathrm{CO}_{2}$ in plant sap is inhibition of the reversible decarboxy lation reactions of the respiratory systems (Isenberg, 1979).

Flower bud development (Fig. 2) and bloom (Fig. 3) of trees sprayed with $2.5 \%$ to $20 \%$ CSO were delayed. Trees treated with 10910 CSO bloomed about 6 days later than untreated trees. Trees treated with repeated applications of 5\%. CSO bloomed about 4 


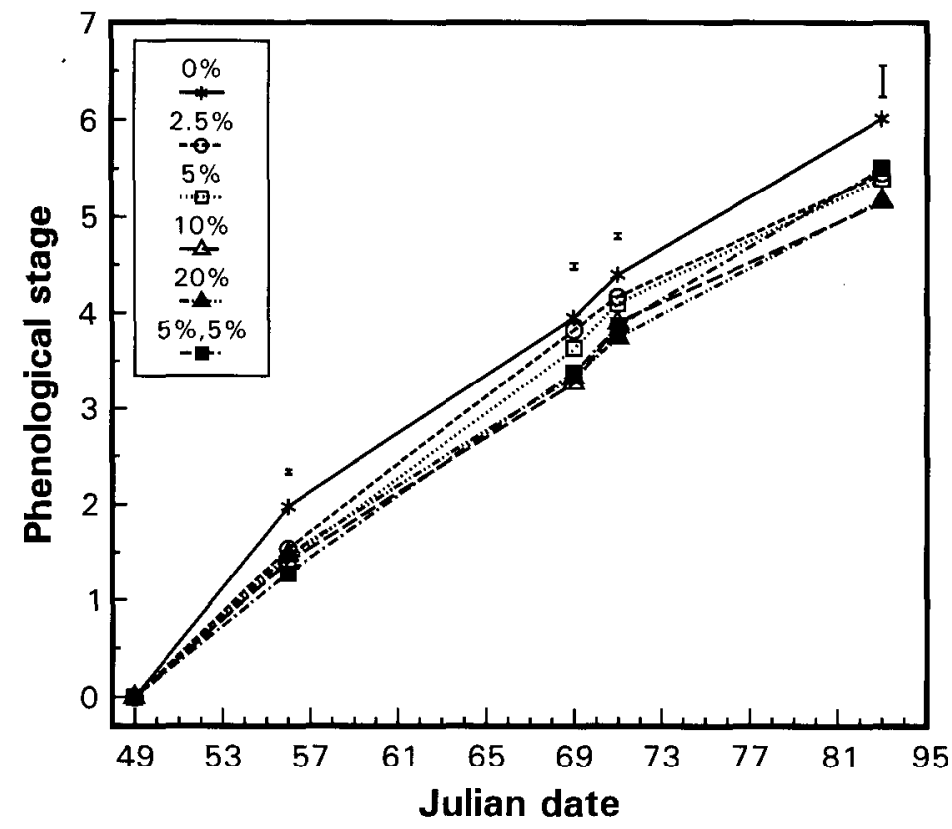

Fig. 2. Phonological development of 'Georgia Belle' peach flower buds on trees treated with $0 \%, 2.5 \%, 5.0 \%, 10 \%$, or $20 \%$ crude soybean oil on 11 Feb. or with $5 \%$ crude soybean oil on $1 \mathrm{I}$ and 24 Feb. 1992. Vertical bars $=$ SE.

days later than trees receiving a single application of 5\% CSO and 1 day later than trees receiving a single application of $10 \%$ CSO.

Spraying trees with CSO caused damage to flower buds. Slight browning of anthers and pistils of dissected buds were observed two weeks after treatment, but browning was darker and more distinct one month after treatment. Damaged buds were distributed throughout the basal, medial, and apical section of shoots (data not shown). Death of flower buds on the tagged shoots increased (Fig. 4) and viable flower bud density decreased with increased CSO concentration. Death of flower buds from repeated applications of $5 \%$ oil was no higher than from a single application and was about $10 \%$ lower than bud death resulting from a single $10 \%$ application.

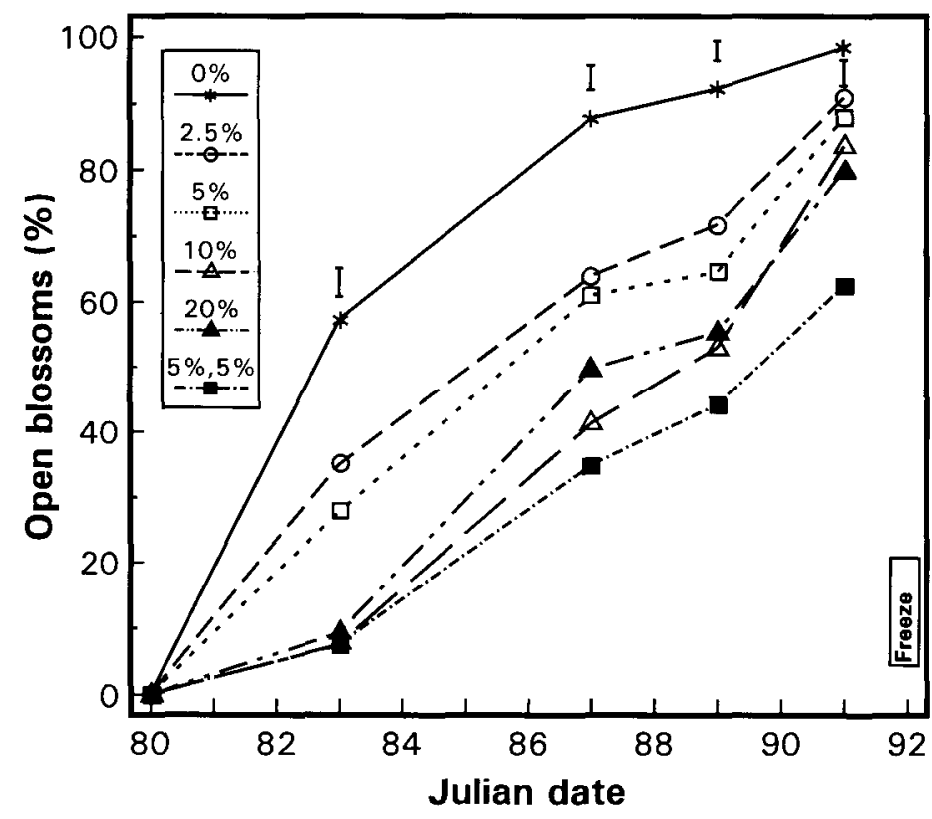

Fig. 3. Open blossoms on 'Georgia Belle' peach trees treated with 070, 2.5\%, 5.070, $10 \%$, or $20 \%$ crude soybean oil on 11 Feb. or with $5 \%$ crude soybean oil on 11 and 24 Feb. 1992. Vertical bars $=$ SE.

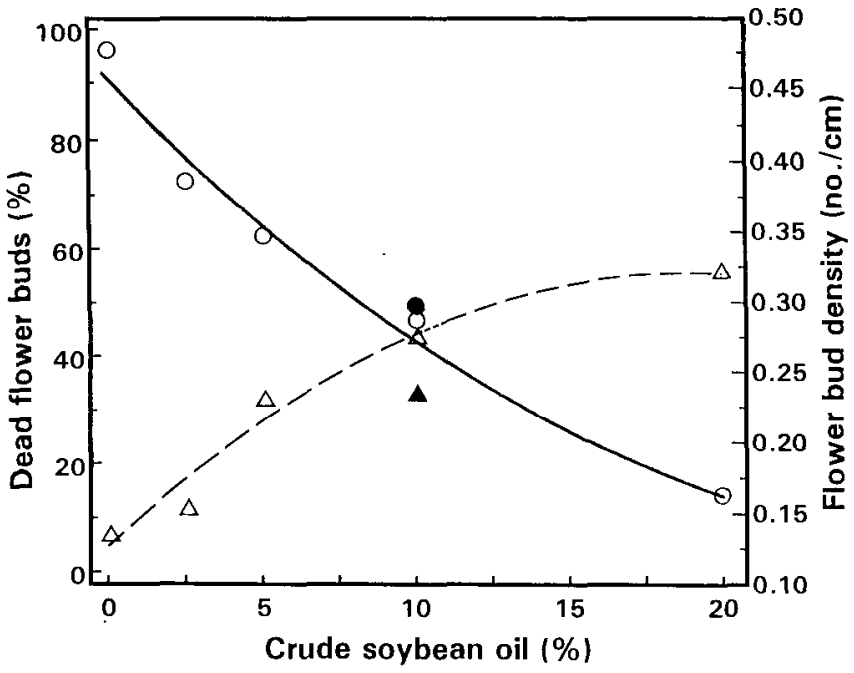

Fig. 4. Relation between crude soybean oil sprayed on 11 Feb. 1992 to the percentage of 'Georgia Belle' peach flower buds dead at anthesis (--- $\Delta---)(y=4.84$ $\left.+5.35 \mathrm{x}-0.14 \mathrm{x}^{2}, \mathrm{r}=0.984\right)$ and peach flower bud density at anthesis $\left(-\mathrm{O}_{-}\right)(\mathrm{y}=$ $\left.0.464-0.0228 \mathrm{x}+0.0004 \mathrm{x}^{2}, r=0.992\right)$. Bud death $(\boldsymbol{\Delta})$ and bud density ( $\left.\boldsymbol{O}\right)$ of trees treated with $5 \%$ crude soybean oil on 11 and 24 Feb. is shown.

However, the viable flower bud density of repeated 5\% sprays was similar to that on shoots treated with $10 \%$ oil. Thus, soybean oil may be used to thin flower buds plus delay development of the remaining buds.

Experiment 2. Degummed soybean oil (DSO) had similar effects as crude soybean oil the previous year on internal $\mathrm{CO}_{2}$ concentration of shoots. Shoots of trees treated with a single application of $5 \%$ to $15 \%$ DSO had higher $\mathrm{CO}_{2}$ concentrations than untreated shoots for 5 days (Fig. 5). The respiration rates of DSO treated shoots were lower than untreated shoots for the first 8 days following treatment. However, the respiration rates of treated shoots were higher than untreated shoots 15 days after treatment. A delayed short elevation of respiration was also noted in an earlier experiment (data not shown). The internal $\mathrm{CO}_{2}$ level in shoots receiving a second application of 5\% DSO was elevated for the first 5 days after the second treatment. Respiration rates of shoots receiving a second application of $2.5 \%$ or $5.0 \%$ soybean oil were not lower than the control the day after treatment but tended to be lower 5 days after treatment. As found for CSO in 1992, treatment with DSO did not significantly affect concentrations of $\mathrm{O}_{2}$ in shoots (data not shown).

Ethylene production by shoots from trees sprayed with $5 \%$ or $10 \%$ DSO were about double those of controls for the first 28 days after treatment (Fig. 6). Zimmerman et al. (1977) suggested that ethylene may influence growth and development of crabapple buds after budbreak. Paiva and Robitaille (1978) concluded that elevated ethylene in apple buds, caused by application of ethephon at the end of rest, did not influence bud break. Crisosto et. al ( 1989) reported that peach flower buds treated in the fall with ethephon had elevated internal ethylene and ABA levels that apparently delayed bloom by slowing floral development. However, Crisosto et al. (1987) earlier reported that spraying peach trees with ethephon just after the completion of chilling requirements increased internal ethylene concentration of buds at bloom by $50 \%$ but did not affect bloom time or fruit set. Though ethylene concentration was increased by soybean oil in this experiment, the concentration of ethylene never exceeded $30 \mathrm{nl} \cdot \mathrm{g}^{-1} \cdot \mathrm{h}^{-1}$. Crisosto et al. (1987) reported that internal ethylene concentrations elevated to 0.63 $\mathrm{ml} \cdot$ liter $^{-1}$ without effect on bloom. We suspect that elevated ethylene in this experiment was not the cause of delayed development 


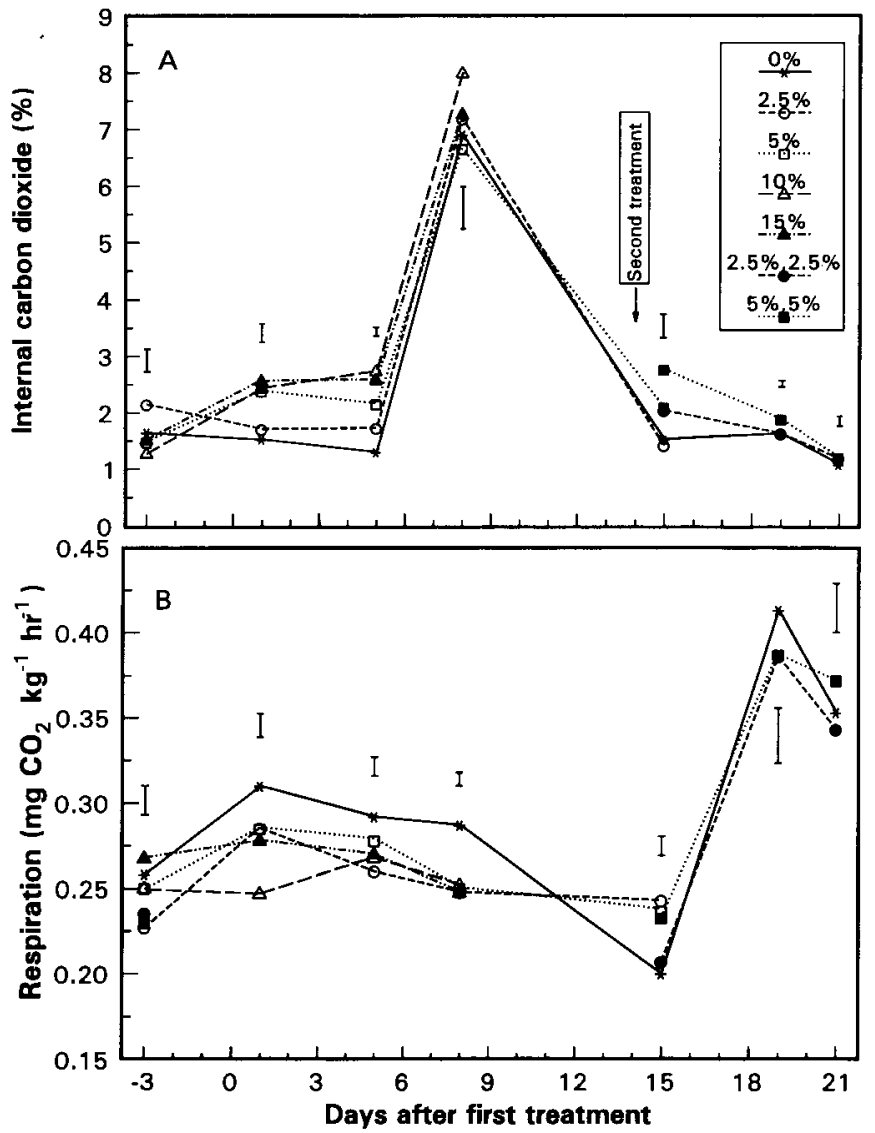

Fig. 5. (A) Internal carbon dioxide content of stems from 'Redhaven' peach trees treated with $0 \%, 2.5 \%, 5.0 \%, 10 \%$, or $15 \%$ degummed soybean oil on $25 \mathrm{Jan}, 1993$ or with repeated sprays of $2.5 \%$ or $5 \%$ degummed soybean oil on 25 Jan. and 8 Feb. 1993. (B) Respiration rates of buds-stems treated with degummed soybean oil, Respiration rates and $\mathrm{CO}$, content of stems receiving repeated applications were not collected until after the second application. Vertical bars $=$ SE.

of flower buds but is a response to injury of shoots or buds.

Flower bud development was delayed by DSO in 1993 similar to the delay by CSO in 1992. Bloom was delayed more by higher

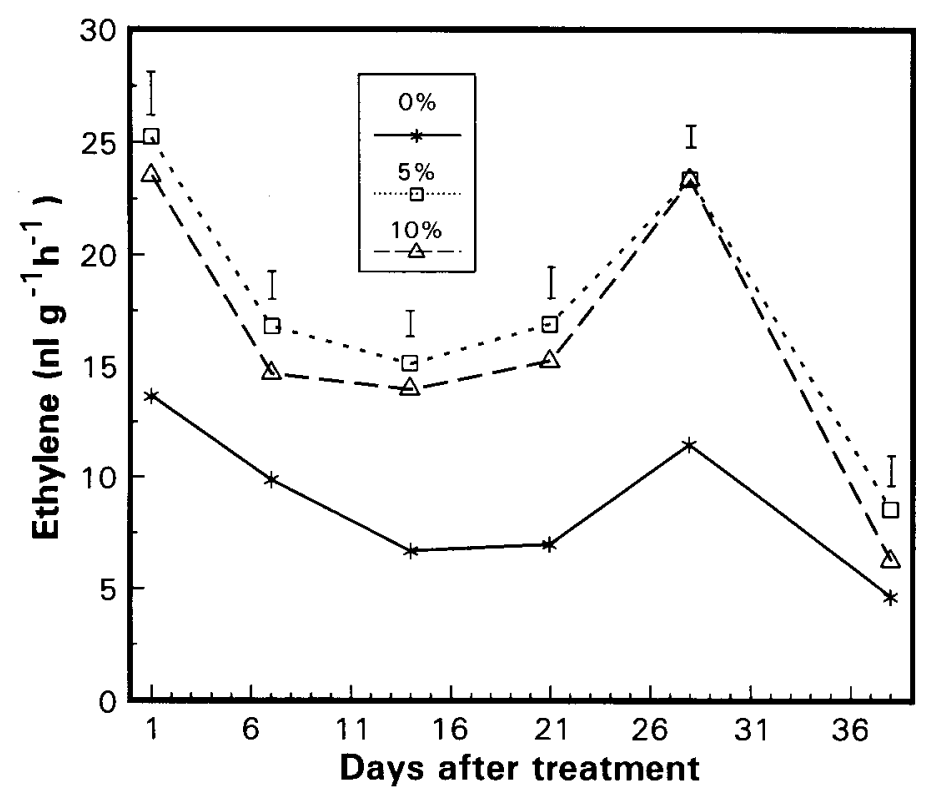

Fig. 6. Ethylene evolution of stems from 'Redhaven' peach trees treated with 0\%, $5.0 \%$, or $10 \%$, degummed soybean oil on 25 January 1993. Vertical bars = SE.

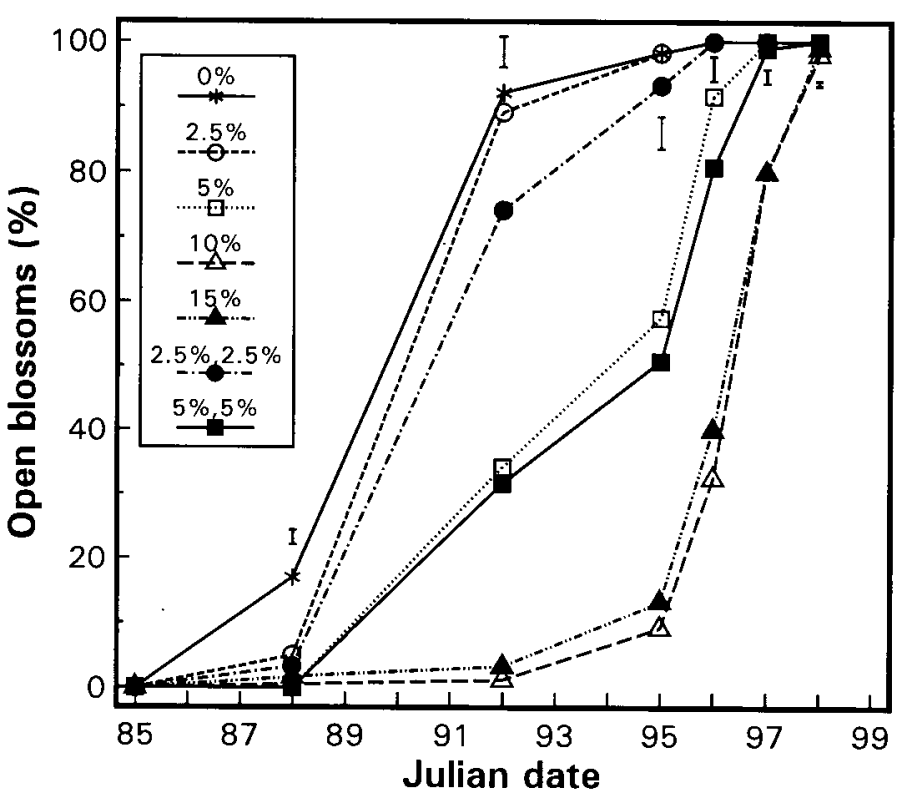

Fig. 7. Open blossoms on 'Redhaven' peach trees treated with single applications of $0 \%, 2.5 \%, 5.0 \%, 10 \%$, or $15 \%$ degummed soybean oil on 25 Jan, 1993 or with repeated sprays of $2.5 \%$ or $5 \%$. degummed soybean oil on 25 Jan. and 8 Feb. 1993. Vertical bars $=$ SE.

concentrations of DSO (Fig. 7). Spraying trees with 5\% DSO resulted in a 4 day delay in bloom. Multiple applications of $2.5 \%$ or $5 \%$ DSO delayed bloom less than one day longer than single applications of DSO. Application of $10 \%$ or $15 \%$ DSO caused the greatest delay of bloom (about 6 days).

In general, the number of fruit and yield per tree decreased and

Table 1. Effects of dormant applications of degummed soybean oil on yield of 3-year-old 'Redhaven' peach trees at Knoxville, Term., in 1993.

$\begin{array}{lccc}\text { Soybean oil }(\%) & \begin{array}{c}\text { No. of } \\ \text { applications }\end{array} & \begin{array}{c}\text { Yield } \\ \text { (no. fruit/three) }\end{array} & \begin{array}{c}\text { Fruit size } \\ (\mathrm{g})\end{array} \\ 0.0 & 1 & 923 & 41 \\ 2.5 & 1 & 772 & 49 \\ 5.0 & 1 & 330 & 70 \\ 10.0 & 1 & 98 & 87 \\ 15.0 & 1 & 118 & 81 \\ 2.5 & 2 & 570 & 54 \\ 5.0 & 2 & 487 & 65 \\ \text { L S D }_{0.05} & & 210 & 12\end{array}$

Table 2. Effects of degummed soybean oil and petroleum oil on flower bud density, fruit set, and yield of 'Redhaven' peach trees at Spring Hill, Term., in 1993.

\begin{tabular}{|c|c|c|c|c|c|}
\hline hemical & $\begin{array}{c}\text { Concn } \\
(\%)\end{array}$ & $\begin{array}{l}\text { Density }^{2} \\
(\text { no./cm) }\end{array}$ & $\begin{array}{c}\text { Flower } \\
\text { density }^{y} \\
(\text { no./cm) }\end{array}$ & $\begin{array}{c}\text { Fruit } \\
\text { yield } \\
(\mathrm{kg} / \text { tree })\end{array}$ & $\begin{array}{c}\text { Fruit size } \\
(\mathrm{g})\end{array}$ \\
\hline & o & 0.45 & 0.13 & 43.7 & 100 \\
\hline ybean oil & 6 & 0.44 & 0.09 & 54.7 & 115 \\
\hline ybean oil & 9 & 0.20 & 0.08 & 51.3 & 119 \\
\hline ybean oil & 12 & 0.15 & 0.06 & 43.0 & 113 \\
\hline roleum oil & 6 & 0.50 & 0.12 & 36.0 & 99 \\
\hline roleum oil & 9 & 0.43 & 0.11 & 39.7 & 110 \\
\hline roleum oil & 12 & 0.44 & 0.12 & 40.6 & 109 \\
\hline $\mathrm{D}_{0.05}$ & & 0.06 & 0.03 & 18.9 & 17 \\
\hline
\end{tabular}

${ }^{2}$ Number of flowers/cm of stem on 1 Apr. 1993.

${ }^{y}$ Number of fruit/cm of stem on 26 May 1993. 
fruit size increased as DSO concentration increased (Table 1 ). We judged that untreated trees and $2.5 \%$ DSO trees had too many fruit (not hand thinned) to allow development of fruit to a desirable size in most years. However, treatments of $10 \%$ and $15 \%$ oil resulted in over thinning of the crop. The 5\% and repeated $5 \%$ oil treatments left more desirable numbers of fruit on the trees. The dry growing season greatly affected the sizing of the fruit in this study.

Experiment. The 8-year old trees at Spring Hill had $0.58 \pm 0.02$ flower buds per $\mathrm{cm}$ of stem at the time of treatment. About $85 \%$ of the fruit buds on tagged shoots of untreated trees developed flowers (1 Apr.), even though exposed to $-14 \mathrm{C}$ at 24 days (first swell) before first bloom. Trees treated with $6 \%-12 \%$ petroleum had similar bloom density as the control (Table 2). Our previous research (Deyton et al., 1992) indicated that 12\% petroleum oil killed almost $40 \%$ of buds. The freeze at first bud swell may have killed more flower buds on control trees than treated trees, partially explaining the similar bloom densities. Other undetermined factors resulted in less bud kill from treatment with $9 \%-12 \%$ petroleum oil than seen in three other experiments.

Application of $9 \%$ or $12 \%$ DSO reduced flower density to less than half that of untreated trees (Table 2). The trees were exposed to $-6 \mathrm{C}$ on 3 Apr., when untreated trees had about $60 \%$ open bloom. Bloom of trees treated with $9 \%$ or $12 \%$ soybean or petroleum oil was delayed by 2 to 4 days (data not shown). Trees sprayed with 6 or $9 \%$ soybean oil had $>17 \% \%$ more yield (weight) than control trees and $>29 \%$ more yield than petroleum oil treated trees (Table 2). This indicates that although bud death was higher in the DSO treated trees the remaining buds were more likely to produce viable fruit.

We have shown that dormant sprays of soybean oil modified internal $\mathrm{CO}_{2}$ concentration of peach shoots and reduced respiration. This could result in a CA-like condition within the oil enveloped shoots. Flower bud development was delayed which should result in greater cold tolerance of buds (Call and Seeley, 1989). Bloom was delayed by up to 6 days in 1992 and 1993. Higher rates $(\geq 10 \%)$ of soybean oil caused more bud death. Repeated applications of lower rates of oil may be a means of reducing bud death and causing more delay of bloom. One approach of timing a repeated application may be to monitor the elevated $\mathrm{CO}_{2}$ in shoots or the reduced respiration rates and respray when oil appears to no longer have an influence. The use of higher rates of soybean oil may be a viable commercial method to thin peach fruit.

\section{Literature Cited}

Blouin, D.C and A.M. Saxton. 1990. General linear mixed models GLMM (version 1.0) user's manual. Dept. Expt. Stat., Louisiana Agr. Sta., Baton Rouge, La.

Burroughs, A.M. 1923. Effects of oil sprays on fruit trees. Proc. Amer. Soc. Hort. Sci. 20:269-277.

Call, R.C. and S.D. Seeley. 1989. Flower bud coatings of spray oils delay rehardening and bloom in peach trees. HortScience 24:914-915.

Crisosto, C.H., P.B. Lombard, and L.H. Fuchigami. 1987. Spring applications of ethephon and ethylene inhibitors on bloom delay, fruit set, and yield in 'Redbaven' peach. Acta Hort. 210: 195-201.

Crisosto, C.H., P.B. Lombard, and L.H. Fuchigami. 1989. Fall ethephon delays bloom in 'Redhaven' peach by delaying flower differentiation and development during dormancy. J. Amer. Soc. Hort. Sci. 114:881-884.

Deyton, D.E., Carl E. Sams, and John C. Cummins. 1992. Application of dormant oil to peach trees modifies bud-twig internal atmosphere. HortScience 27:1304-1305.

Farrar, M.D. and V.K. Kelley. 1935. The accumulative effect of oil sprays on apple trees. J. Econ. Entomol. 28:260-263.

Isenberg, F.M.R. 1979. Controlled atmosphere storage of vegetables, p. 337-394. In: J. Janick (cd.) Horticultural reviews. AVI Publ. Co., Westport, Corm.

Paiva, E. and H.A. Robitaille. 1978. Breaking bud rest on detached apple shoots: effects of wounding and ethylene. J. Amer. Soc. Hort. Sci. 103:101-104.

Pless, C.D. 1995. Control of San Jose scale, terrapin scale, and European red mite on dormant fruit trees with soybean oil. HortScience 30:94-97.

Robertson, G.L. 1993. Food packaging: Principles and practice. Marcel Dekker. New York, p. 86-87.

Saltveit, M.E., Jr. 1982. Procedures for extracting and analyzing internal gas samples from plant tissues by gas chromatography. HortScience $17: 878-881$

Smock, R.M. 1978. Controlled atmosphere storage of fruits, p.301-36. In: J. Janick (cd.). Horticultural reviews., vol 1., AVI, Westport, Corm.

Westwood, M.N. 1993. Temperate-zone pomology. 3rd ed. Timber Press, Portland, Ore.

Young, E. and S.M. Blankenship. 1991 Low oxygen delays budbreak of apple trees in greenhouse and prolongs storage. HortScience 26:890-891.

Zimmerman, R.H., M. Liberman, and O.C. Broome. 1977. Inhibitory effect of a rhizobitoxine analog on bud growth after release from dormancy. Plant Physiol. 59:158-160. 